\title{
EFFECT OF ADDITION OF DEINKED PULP TO BLEACHED KRAFT PULP ON TISSUE PAPER PROPERTIES
}

\author{
Monika Stankovská, Mária Fišerová, Juraj Gigac, Elena Opálená \\ Pulp And Paper Research Institute \\ Slovak Republic
}

(Received April 2020)

\begin{abstract}
The influence of addition of deinked pulps with low and high brightness to bleached eucalyptus and pine kraft pulps on functional tissue paper properties was studied. Deinked pulps with low and high brightness had some different functional properties. Deinked pulp with high brightness has higher bulk, porosity, water absorption after immersion, initial water absorption, bulk softness as well as brightness. On the contrary, the difference in relative bonded area and porosity $\varepsilon$ between deinked pulps with low and high brightness was moderate. The mixed pulps laboratory pulp sheets from bleached eucalyptus kraft pulp or bleached pine kraft pulp with addition of 20, 40 and 80\% of deinked pulp with low brightness or deinked pulp with high brightness were prepared. The addition of the deinked pulp with high or low brightness to bleached kraft pulp leads to increasing of bulk, bulk softness as well as high water absorption after immersion and initial water absorption. The tensile index rapidly decreased by the addition of deinked pulps with high brightness to bleached eucalyptus and pine kraft pulps. Similarly, the addition of deinked pulp with low brightness to bleached pine kraft pulp led to rapid decreasing of tensile index. On contrary, with the addition of deinked pulp with low brightness to eucalyptus kraft pulp, the decreasing of tensile index was less pronounced. Mixed pulp from bleached eucalyptus kraft pulp with a small content of deinked pulp with low brightness with functional properties suitable for production of tissue papers was found as optimal.
\end{abstract}

KEYWORDS: Hardwood kraft pulp, softwood kraft pulp, deinked pulp, water absorption, tensile index, bulk softness, optical properties, tissue paper. 


\section{INTRODUCTION}

Paper production from recycled fibres is environmentally friendly as it saves forests and at the same time eliminates the problem of its disposal. Recycled paper processing is becoming part of companies' environmental strategy. With the repeated use of recycled paper, the properties of paper change with the increase of the recycle number, especially the strength properties due to changes in the morphological structure of the fibres as well as due to interfibre bonding during beating and drying of pulp. Although the use of recycled fibres can significantly reduce the use of raw materials as well as energy consumption in tissue paper production, some toxic substances, such as mineral oils and heavy metals, remain in recycled fibres. When recycled fibres were used in food packaging materials, the contamination of food products was found (Biedermann et al. 2010, Sturaro et al. 2006). Another common practice is to add a fluorescent whitening agent to remove the negative effect of residual ink in the recycled fibres on the brightness of the paper, but fluorescent whitening agent is also toxic (Tirado et al. 2009). Therefore, the use of recycled fibres in the production of tissue paper poses a risk that customers may come into contact with these harmful substances.

Paper production and recycling processes lead to surface and volume changes of cellulosic fibres. The basic effects of recycling on pulp properties have already been presented in detail in works (Howard and Bichard 1992, Howard 1995). Recycled fibres have low swelling ability and wet flexibility, especially dried kraft fibres, which leads to a reduction in inter-fibre bonding and bonded area. Recycled fibres are shorter and have a higher content of fines than the virgin fibres (Hubbe et al. 2007, McKinney 1995). In addition, if kraft fibres are refined before drying during the production of paper, a further greater loss in fibre splicing is expected when the same fibres are recycled (Hubbe et al. 2007). The magnitude of the drying-induced strength loss of recycled fibres varies with the nature of the original fibre. Chemical pulps with very low lignin contents are more susceptible to loss of tensile or bonding strength than other types of pulp. Dry-fiberized newsprint pulp produces paper sheets of low strength due to shortened fibres and a loss of surface fibrillation. Minor and Atalla (1992) attempted to develop a new paper recycling process that required substantially less water than current processes and the water-intensive repulping where paper forming steps were replaced with dry-fiberizing, air-forming, gas-phase ozone and ammonia treatments, and press drying. In the case of mechanical pulps, the recycling process increases the collapse and flexibility of the fibres, leading to better fibre bonding and improved paper strength. It was illustrated (Scallan and Tigerstrom 1992) that high yield pulps such as thermomechanical (TMP) and chemi-thermomechanical pulp (CTMP) can recover the ability to take-up water following a drying treatment, while lower yield pulps cannot. Among the different types of mechanical pulps, CTMP pulp has a faster response to the recycling process than TMP pulp. CTMP pulp has lower fibre wall stiffness than other mechanical pulps (McKinney 1995).

Recycled fibres generally contribute to a reduction in bulk and surface softness compared to the original fibres. Recycled fibres are rigid and are unable to provide the required flexibility needed for good surface softness and strength. Although the recycling process reduces the fibre bonding capacity, recycled fibres have been previously refined and thus have a higher bonding capacity than unrefined fibres from hardwood, leading to a reduction in bulk softness (McKinney 1995). On the other hand, recycled fibres have lower swelling and are stiffer and more dimensionally stable; the results are papers with greater bulk and absorbency (McKinney 1995, Hubbe et al. 2007). Recycled fibres can potentially be used to reduce fibre bonding. Brightness of handsheets made from recycled pulps tested by Ali (Ali 2006) showed that it slightly increased 
initially and then decreased with recycling where the initial increase in light reflectance may be attributed to the loss of fines changing the network structure of paper.

To improve the strength of recycled fibres, mechanical refining is a common approach used by paper manufacturers. However, the refining of recycled fibres must be considered carefully. Most recycled fibres have already been refined once, and recycled fibres are expected to be more susceptible to fragmentation than the virgin fibres. Refining of previously dried fibres leads only to a partial recovery of lost strength. Loss of bonding is observed even when recycled fibres are refined to the same degree of refining as they were before their first drying (McKinney 1995, Hubbe et al. 2007). It can be expected that the use of high intensity refining will increase the tensile strength of some fibres, but also increase the number of fines which leads to reduction of the dewatering rate. The using of high consistency refining can be considered as a better alternative as this refining will reduce the contact between the surface of the refiner and the fibres, where fibre fragmentation may occur (de Ruvo and Htun 1983). Another common approach to minimizing the limitations associated with recycled fibres is blending them with flexible and fibrillated virgin fibres. A high $\mathrm{pH}$ medium can also be used to restore the swelling and flexibility of the fibres, although this approach will cause significant delignification. Limitations in fibre bonding can also be overcome by the using of additives, e.g. cationic starch to wet end of a paper machine (McKinney 1995, Hubbe et al. 2007).

Improving strength properties of mixture from recycled and virgin fibres pulp is possible with the addition of dry strength agents (Gulsoy and Erenturk 2017). In order to improve the strength properties of recycled old corrugated carton pulp, various polymers as chitosan, cationic starch and polyvinyl alcohol (Hamzeh et al. 2013) as well as blending with virgin fibres of kenaf pulp (Latifah et al. 2009) were used. The bonding ability of borax might help in improving the strength properties of recycled paper from bleached softwood kraft pulp (Devisetti 1999). Restoring strength of recycled fibres from old cardboard, copy paper and newspaper by blending them with oil palm empty fruit bunch was studied (Rushdan 2003). Blending of recovered fibres with unbleached spruce pulp of $30 \%$ content showed also improvement of strength properties of paper handsheets (Fišerová et al. 2012).

The objective of the work was to determine the effect of blending of deinked pulps with bleached hardwood or softwood kraft pulp on functional properties of tissue paper.

\section{MATERIAL AND METHODS}

\section{Materials}

Bleached pine kraft pulp (Pine) - Södra Black was made from juvenile pine trees. Bleached eucalyptus kraft pulp (Eucalyptus) - Pontevedra was made from eucalyptus wood. Deinked pulp with low brightness 59.5\% ISO (DIP LB) was prepared in Metsä Tissue Krapkowice mill from $57 \%$ of waste papers Group No. 1 "Ordinary grades", 38\% of Group No.3 "High grades" according to EN 643: 2014 and 5\% of cartons. Deinked pulp with high brightness 73,5\% ISO (DIP HB) was prepared in Metsä Tissue Krapkowice mill from $80 \%$ of waste papers Group No. 3 "High grades" according to EN 643: 2014 and 20\% of broke from production of hygienic paper from bleached pulp. The total lignin content in deinked pulp was $5.8 \%$.

\section{Methods}

The bleached softwood and hardwood kraft pulps were beaten to $20^{\circ} \mathrm{SR}$ in a laboratory Jokro mill according to ISO 5264-3:1979. Low drainage resistance was chosen for pulps as pulp beating 
markedly reduces water absorption, bulk softness and brightness (Fišerová et al. 2019). Bleached eucalyptus kraft pulp or bleached pine kraft pulp was mixed with 0, 20, 40 and 80\% of deinked pulp with low brightness or deinked pulp with high brightness. The hand sheets $\left(60 \mathrm{~g} \cdot \mathrm{m}^{-2}\right)$ were prepared in the Rapid Köthen sheet former according to ISO 5269-2:2004.

\section{Analysis}

Porosity $\&$ was calculated according to the equation given in literature (Daub et al. 1986). The bulk was calculated from the apparent bulk density determined according to ISO 534: 2012. Water absorption after immersion for time of $10 \mathrm{~s}$ was determined according to the standard ISO 5637: 1989.

Relative bonded area was calculated according to Equation 1 based on the light scattering coefficient $S$ and $S_{0}$. The light scattering coefficient $S\left(\mathrm{~m}^{2} \cdot \mathrm{kg}^{-1}\right)$ was measured on Elrepho 2000 colorimeter according to ISO 9416: 2017. The light scattering coefficient $S_{0}$ was evaluated from the linear dependence between the light scattering coefficient $S$ and the tearing index where the light scattering coefficient $\mathrm{S}_{0}$ was read when the tearing index was extrapolated to zero value. This method was described in work of Ingmanson and Thode (1979).

$$
R B A=\frac{\mathrm{S}_{0^{-}} \mathrm{S}}{\mathrm{S}_{0}} \times 100
$$

where: S - light scattering coefficient for sheet $\left(\mathrm{m}^{2} \cdot \mathrm{kg}^{-1}\right)$ which was prepared in water and thus the interfibre bonds were formed, $S_{0}$ - light scattering coefficient of fibres in unbonded states.

Water penetration dynamics were measured by the ultrasound device PDA C.02 (Emtec, Radnor, PA, USA) with a frequency of $2 \mathrm{MHz}$. Water with a surface energy of $72 \mathrm{~mJ} \cdot \mathrm{m}^{-2}$ was used as the test liquid. Ultrasound signal intensity (USI) change was obtained at $43 \mathrm{~ms}-60 \mathrm{~s}$ using the $\mathrm{SC}$ algorithm. The algorithm for calculating initial water absorption was designed from the USI drop in $200 \mathrm{~ms}$. A more detailed description of this method as well as an evaluation process of the initial water absorption has already been published (Stankovská et al.2019).

The tensile index was determined according to ISO 1924-2a (2008). The bulk softness was calculated from the bending stiffness determined at $15^{\circ}$ and $10 \mathrm{~mm}$ distance between the clamp and the knife-edge according to TAPPI T 556 pm-95 method. The brightness was determined according to ISO 2470-1: 2016 and colour coordinate $b^{*}$ according to ISO 5631-1: 2015.

\section{RESULTS AND DISCUSSION}

\section{Porosity, bulk and water absorption of mixed pulps}

The addition of deinked pulps to bleached kraft pulps results in an increase in porosity $\varepsilon$ as shown in Fig.1a. Porosity of deinked pulps was higher than the bleached kraft pulps. By increasing the addition of deinked pulps, the porosity increased evenly. The addition of the deinked pulp with high brightness (full line) changes porosity more markedly than the addition of the deinked pulp with low brightness (dashed line). The bulk of pulp significantly influences the water absorption after immersion and initial water absorption (Stankovská et al. 2019) as well as softness (Morais et al. 2019) of pulp sheet. Deinked pulps had a higher bulk than the bleached kraft pulps. Deinked pulp with high brightness had a higher bulk than the deinked pulp with low brightness (Fig. 1b). Recycled fibres that have been dried in the past are stiffer and less flexible, which results in higher bulk; this is desirable for the production of tissue papers. The addition of deinked pulps to bleached kraft pulps increased significantly the bulk; the shape of the curves is very similar to the shape of the curves of porosity (Fig. 1a). The addition of deinked pulps to bleached 
kraft pulps increased significantly the bulk; the shape of the curves is very similar to the shape of the porosity curves (Fig. 1a). As in the case of porosity, the addition of the deinked pulp with high brightness affected the change in bulk more significantly than the addition of the deinked pulp with low brightness.

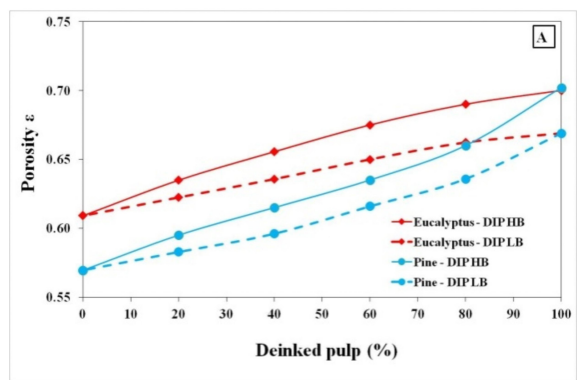

(a)

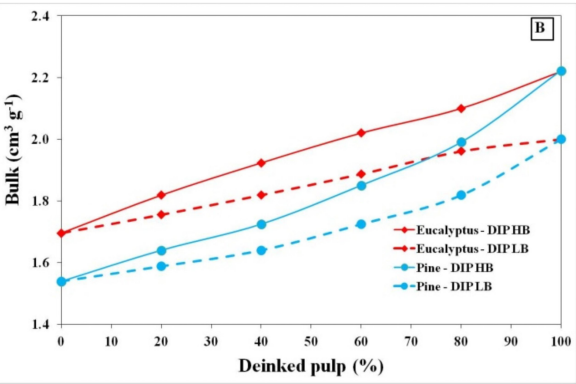

(b)

Fig. 1: Influence of addition of deinked pulp with high brightness (DIP HB) or deinked pulp with low brightness (DIP LB) to bleached eucalyptus kraft pulp (eucalyptus) or to bleached pine kraft pulp (pine) on porosity (a), and bulk (b).

The effect of deinked pulps addition to bleached kraft pulps on the water absorption after immersion is shown in Fig. 2a. Deinked pulp with high brightness had significantly higher water absorption after immersion than deinked pulp with low brightness. The addition of deinked pulp with high brightness to bleached softwood or hardwood kraft pulp increased the water absorption after immersion significantly while the addition of deinked pulp with low brightness has less effect. The initial water absorption of the deinked pulps was significantly higher than thebleached kraft pulps (Fig. 2b). By comparison of deinked pulps, deinked pulpwith high brightness had higher initial water absorption (455\%) than that of low brightness (387\%). With increasing addition of deinked pulps to bleached kraft pulps, the initial water absorption increased. The addition of deinked pulp with high brightness to bleached eucalyptus kraft pulp or bleached pine kraft pulp increased the initial water absorption very significantly, with bleached pine kraft pulp even up to 3-6-times. The addition of deinked pulp with low brightness to bleached pine kraft pulp also increased the initial water absorption significantly. The effect of addition of deinked kraft pulp with low brightness to bleached eucalyptus kraft pulp was less pronounced.

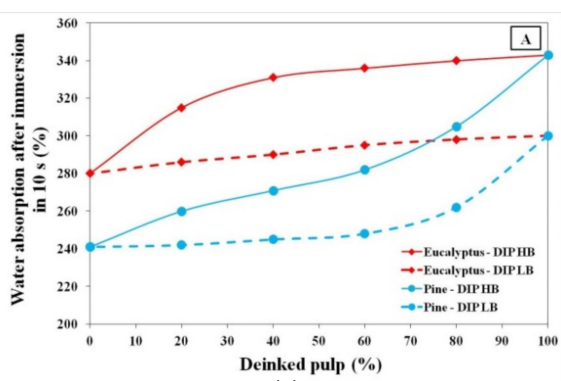

(a)

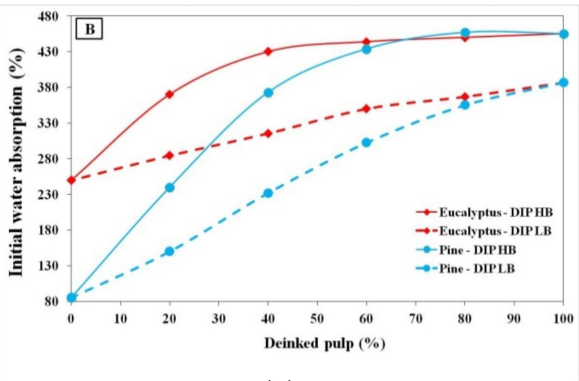

(b)

Fig. 2: Influence of addition of deinked pulp with high brightness (DIP HB) or deinked pulp with low brightness (DIP LB) to bleached eucalyptus kraft pulp (eucalyptus) or to bleached pine kraft pulp (pine) on water absorption after immersion (a), and initial water absorption (b). 


\section{Relative bonded area of mixed pulps}

The relative bonded area has proved to be suitable tools for prediction of initial water absorption of bleached softwood and hardwood kraft pulps (Stankovská et al. 2019). The relative bonded area between the two types of deinked pulps did not differ significantly (Fig. 3). The addition of deinked pulps to the bleached kraft pulps leads to decreasing of relative bonded area, as the recycled fibres are less flexible than virgin fibres.

With the addition of deinked pulps to bleached eucalyptus kraft pulp, the relative bonded area dropped significantly. The addition of deinked pulp to bleached pine kraft pulp led also to decreasing of relative bonded area, with the addition of $20 \%$ deinked pulp with low brightness decline was more moderate.

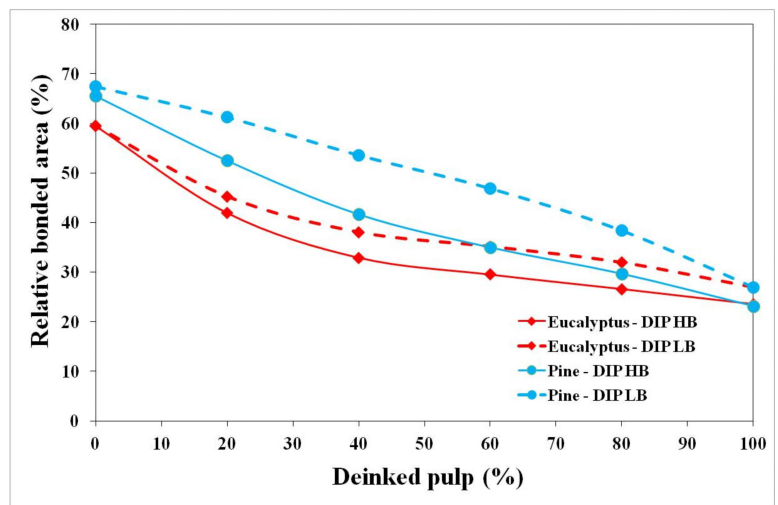

Fig. 3: Influence of addition of deinked pulp with high brightness (DIP HB) or deinked pulp with low brightness (DIP LB) to bleached eucalyptus kraft pulp (eucalyptus) or to bleached pine kraft pulp (pine) on relative bonded area.

A high correlation between the initial water absorption and relative bonded area of the mixture of deinked pulps with bleached eucalyptus and pine kraft pulps has been proven, as shown in Fig.4.

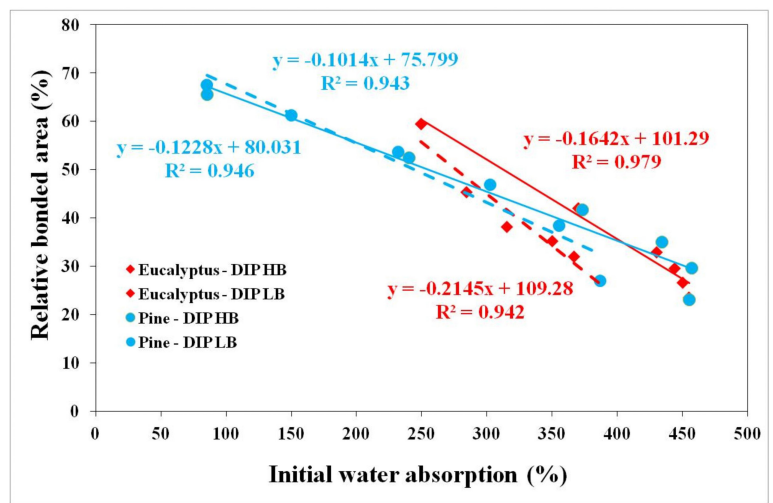

Fig. 4: The relationship between relative bonded area and initial water absorption of mixed pulps from deinked pulp with high brightness (DIP HB) or deinked pulp with low brightness (DIP LB) and bleached eucalyptus kraft pulp (eucalyptus) or bleached pine kraft pulp (pine). 


\section{Tensile index and bulk softness of mixed pulps}

The effect of addition of deinked pulps with different brightness to bleached kraft pulps on the tensile index is shown in Fig. 5a. The tensile index of deinked pulps was significantly lower than that of bleached kraft pulps. Deinked pulp with high brightness had lower tensile index by $61 \%\left(23.2 \mathrm{Nm}^{-1}\right)$ than deinked pulp with low brightness $\left(37.3 \mathrm{Nm} \cdot \mathrm{g}^{-1}\right)$.

The addition of deinked pulp with low brightness to bleached eucalyptus kraft pulp led to uniform decreasing of tensile index. In the case of addition of deinked pulp with high brightness to bleached eucalyptus kraft pulp, the effect on tensile index was more pronounced. As the content of deinked pulp with low brightness in the mixture with bleached pine kraft pulp increased, the tensile index decreased evenly within $12-43 \%$. The addition of deinked pulp with high brightness to bleached pine kraft pulp led to significant and uneven decline of tensile index reduced by 51-64\%. Decreasing of tensile index with addition of deinked pulp can be also significantly affected by the recycle number which may be linked to the reduced bonding ability of repeatedly recycled pulps (Ali 2006).

Deinked pulp with high brightness has higher bulk softness $\left(2.0 \mathrm{mN} \cdot \mathrm{m}^{-1}\right)$ than deinked pulp with low brightness $\left(1.85 \mathrm{mN} \cdot \mathrm{m}^{-1}\right)$. Both types of deinked pulps have higher bulk softness than bleached eucalyptus kraft pulp $\left(1.39 \mathrm{mN} \cdot \mathrm{m}^{-1}\right)$ and bleached pine kraft pulp $\left(1.49 \mathrm{mN} \cdot \mathrm{m}^{-1}\right)$. The addition of both types of deinked pulps to bleached pine kraft pulp significantly improved the bulk softness (Fig. 5b). The addition of $20-80 \%$ of both types of deinked pulps to bleached eucalyptus kraft pulp leads to increase in bulk softness by 3-33\% (deinked pulp with low brightness), respectively by 6-44\% (deinked pulps with high brightness). In case of $20-80 \%$ addition of both types of deinked pulps to bleached pine kraft pulp, there was an almost uniform increase of bulk softness from 5 to $20 \%$.

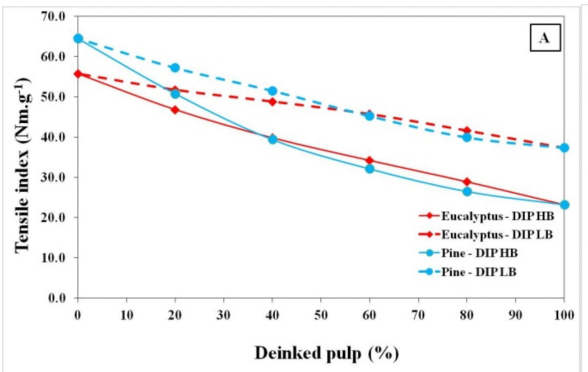

(a)

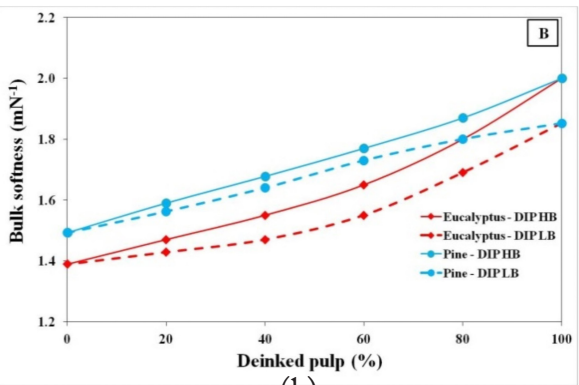

(b)

Fig. 5: Influence of addition of deinked pulp with high brightness (DIP HB) or deinked pulp with low brightness (DIP LB) to bleached eucalyptus kraft pulp (eucalyptus) or to bleached pine kraft pulp (pine) on tensile index (a), and bulk softness (b).

\section{Optical properties of mixed pulps}

The effect of the addition of deinked pulps to bleached kraft pulps on brightness has been shown to be more pronounced for deinked pulps with low brightness and the shape of the curves is almost identical for bleached eucalyptus and pine kraft pulp (Fig. 6a). With increased addition of deinked pulp with low brightness to bleached pine and eucalyptus kraft pulps, the brightness decreased by $14-28 \%$ (pine) and 11-26\% (eucalyptus). The effect of deinked pulp addition with higher brightness to bleached eucalyptus and pine kraft pulp was similar, resulted in declination by $5-17 \%$. 


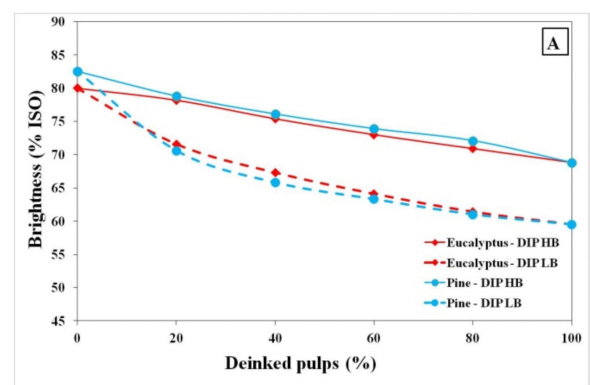

(a)

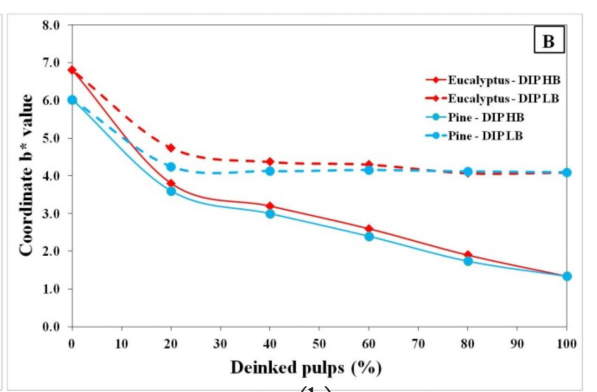

(b)

Fig. 6: Influence of addition of deinked pulp with high brightness (DIP HB) or deinked pulp with low brightness (DIP LB) to bleached eucalyptus kraft pulp (Eucalyptus) or to bleached pine kraft pulp (Pine) on brightness (a), and coordinate $b^{*}(b)$.

Fig. $6 \mathrm{~b}$ shows the effect of addition of deinked pulps to bleached pine and eucalyptus kraft pulps on the $b^{*}$ coordinate value, which indicates the yellowness of the pulp sheets. The coordinate $b^{*}$ value of bleached eucalyptus kraft pulp is higher (6.80) than that of bleached pine kraft pulp (6.02). There is a significant difference for deinked pulp with different brightness, when fibres with lower brightness were used, a 3-fold higher coordinate $b^{*}$ value was obtained than with using of deinked pulp with higher brightness. The shape of the curves of the dependence of the coordinate $b^{*}$ on the content of deinked pulps with high brightness in the mixture of bleached pine and eucalyptus kraft pulp is identical. With addition of $20 \%$ of deinked pulps with high brightness to bleached pine and eucalyptus kraft pulp, the coordinate $b^{*}$ value decreased rapidly. When using of deinked pulps with low brightness, the significant decrease of the coordinate $b^{*}$ value occurred only with addition of $20 \%$ and further additions had no more effect.

\section{CONCLUSIONS}

Deinked pulp with high brightness had a higher bulk, air permeability, water absorption after immersion, initial water absorption and bulk softness of the pulp sheet than deinked pulp with low brightness. However, the relative bonded area did not differ significantly. The tensile index of deinked pulp with low brightness was higher by $38 \%$. The addition of deinked pulp with low and high brightness to bleached eucalyptus or pine kraft pulp significantly increased the bulk, volume softness as well as the water absorption after immersion and the initial water absorption. The initial water absorption well correlated with relative bonded area of the mixture of deinked pulps with bleached eucalyptus and pine kraft pulps. The addition of deinked pulps to bleached kraft pulp led to decreasing of tensile index. However, in the case of addition of deinked pulps with low brightness to bleached eucalyptus kraft pulp, the declining slope of the curve is less pronounced. The suitability of using deinked pulp for tissue paper was demonstrated when blending of bleached eucalyptus kraft pulp with a $20 \%$ addition of deinked pulp with low brightness. By this way, bulk softness and water absorption after immersion increased and tensile index almost unchanged when compared to bleached eucalyptus kraft pulp, and in addition, initial water absorption significantly improved. This type of mixed pulp could be used for the production of tissue products where very high softness and brightness is not required whereas, on the other hand, these papers could have a higher yellowness. 


\section{ACKNOWLEDGMENT}

This publication is the result of the project implementation: Centre of Excellence of Forest-based Industry, ITMS: 313011S735) supported by the Research \& Development Operational Programme funded by the ERDF.

\section{REFERENCES}

1. Ali, I., 2012: Study of the mechanical behavior of recycled fibers. Applications to papers and paperboards. Doctoral thesis. Pp 1-241. Université de Grenoble.

2. Biedermann, M., Grob, K., 2010: Is recycled newspaper suitable for food contact materials? Technical grade mineral oils from printing inks. European Food Research and Technology 230(5): 785- 796.

3. Daub, E., Sindel, H., Göttsching, L., 1986: Absorption von Flüssigkeiten in Papier. Das Papier 40(5): 188-197.

4. Devisetti, S.K., 1999: Borax as a strength additive in recycling. Master's Theses 4936. Pp 1-69, Faculty of The Graduate College, Department of Paper and Printing Science and Engineering, Western Michigan University, USA.

5. Fišerová, M., Illa, A., Boháček, Š., Kasajová, M., 2012: Handsheet properties of recovered and virgin fibre blends. Wood Research 58(1): 57-66.

6. Gülsoy, S.K., Erenturk, S., 2017: Improving strength properties of recycled and virgin pulp mixtures with dry strength agents. Starch 69(3-4): 1600035.

7. Hamzeh, Y., Sabbaghi, S., Ashori, A., Abdulkhani, A., Soltan, F., 2013: Improving wet and dry strength properties of recycled old corrugated carton (OCC) pulp using various polymers. Carbohydrate Polymers 94: 577-583.

8. Howard, R.C., Bichard, W., 1992: The basic effects of recycling on pulp properties. Journal of Pulp and Paper Science 18(4): J151-J159.

9. Howard, R.C., 1995: The effects of recycling on pulp quality. In Technology of Paper Recycling Ed. McKinney R.W.J. Pp.180-203, Chapter 6. Blackie Academic \& Professional, New York.

10. Hubbe, M.A., 2006: Bonding between cellulosic fibers in the absence and presence of dry strength agents. A review. BioResources 1(2): 281-318.

11. Ingmanson, W.L., Thode, F.T., 1959: Factors contributing to the strength of the sheet of paper. II. Relative bond area. Tappi 42(1): 83-93.

12. STN EN ISO 534: 2012: Paper and board. Determination of thickness, density and specific volume.

13. STN EN ISO 536: 2012: Paper and board. Determination of grammage.

14. ISO 1924-2: 2008: Paper and board. Determination of tensile properties. Part 2: Constant rate of elongation method $(20 \mathrm{~mm} / \mathrm{min})$.

15. ISO 2470-1: 2016: Paper, board and pulps. Measurement of diffuse blue reflectance factor. Part 1: Indoor daylight conditions (ISO brightness).

16. ISO 5264-3: 1979: Pulps. Laboratory beating. Part 3: Jokro mill method.

17. ISO 5269-2: 2004: Pulps. Preparation of laboratory sheets for physical testing. Part 2: RapidKöthen method.

18. ISO 5631-1: 2015: Paper and board. Determination of colour by diffuse reflectance. Part 1: Indoor daylight conditions ( $\mathrm{C} / 2$ degrees). 
19. ISO 5636-5: 2013: Paper and board: Determination of air permeance (medium range) - Part 5: Gurley method.

20. ISO 5637: 1989: Paper and board. Determination of water absorption after immersion in water.

21. ISO 9416: 2017: Paper. Determination of light scattering and absorption coefficients (using Kubelka-Munk theory).

22. Latifah, J., Ainun, Z.M.A., Rushdan, I., Mahmudin, S., 2009: Restoring strength to recycled fibres by blending with kenaf pulp. Malaysian Journal of Science 28(1): 79-87.

23. McKinney, R.W.J., 1995: Technology of paper recycling. Pp 1-401, First Ed., Blackie Academic\& Professional, Glasgow.

24. Minor,J.L., Atalla, R.H., 1992: Symposium LA - Materials interactions relevant to recycling of wood-based materials 266. Pp 215-228, TAPPI, Atlanta.

25. Morais, F.P., Bértolo, R.A.C., Curto,J.M.R., Amaral, M.E.C.C., Carta,A.M.M.S., Evtyugin, D.V., 2019: Comparative characterization of eucalyptus fibers and softwood fibers for tissue papers applications. Materials Letters: X4: 100028-100032.

26. Rushdan, I., 2003: Structural, mechanical and optical properties of recycled paper blended with oil palm empty fruit bunch pulp. Journal of Oil Palm Bulletin 15(2): 29-36.

27. Ruvo, A.D., Htun, M.,1983: Fundamental and practical aspects of paper-making with recycled fibers. In: The role of fundamental research in paper making, J. Brander (ed.), Vol. 1. Pp 195-225, Mechanical Engineering Pub., Ltd., London.

28. Scallan, A.M., Tigerstrom, A.C., 1992: Swelling and elasticity of the cell walls of pulp fibers. Journal of Pulp and Paper Science 18(5): 188-193.

29. Stankovská, M., Gigac, J., Fišerová, M., Opálená, E., 2019: Relationship between structural parameters and water absorption of bleached softwood and hardwood kraft pulps. Wood Research 64(2): 261-272.

30. Sturaro, A., Rella, B., Parvoli, G., Ferrara, D., Tisato, F., 2006: Contamination of dry foods with trimethyldiphenylmethanes by migration from recycled paper and board packaging. Journal of Food Additives and Contaminants 23(4): 431-436.

31. TAPPIT 556-95 pm method, 1995: Bending resistance of paper and paperboard (Lorentzen and Wettre type tester).

32. Tirado, L.B.M., Area, M.C., Velez, H.E., 2009: Optimizing alkaline sizing in sugar cane bagasse paper recycling. Cellulose Chemistry and Technology 43(4-6): 179-187. 
Monika Stankovská*, Mária Fišerová, Juraj Gigac, Elena Opálená

Pulp And Paper Research Institute

DÚBRAVSKÁ CESTA I 4

84I O4 Bratislava

SLOVAK REPUBLIC

*Corresponding author: stankovska@vupc.sk 
